\title{
EDITORIAL
}

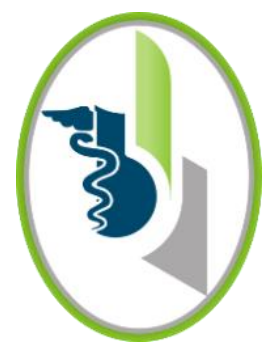

ACCESO ABIERTO

Para citaciones: García, M. (2021). Los efectos ambientales de la pandemia. Revista Ciencias Biomédicas, 10(2), 89-90. https://doi.org/10.32997/rcb-2021-3368

Editor: Inés Benedetti. Universidad de Cartagena-Colombia.

Copyright: (c) 2021. García, M. Este es un artículo de acceso abierto, distribuido bajo los términos de la licencia https://creativecommons.org/licenses/by-nc-

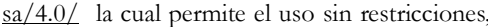
distribución y reproducción en cualquier medio, siempre y cuando el original, el autor y la fuente sean acreditados.

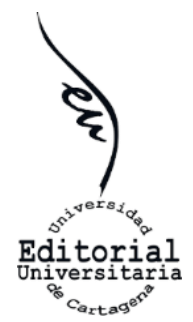

\section{Los efectos ambientales de la pandemia}

Al tiempo que terminaban las baterías de fuegos artificiales y se alzaban copas para festejar el nuevo año 2020, se izaba silenciosa y terrible una amenaza sobre el mundo. La Covid-19, enfermedad infecciosa causada por el virus SARS-CoV2 apareció como una entidad zoonótica en Wuhan, China; se extendió por Asia, Europa y América; recorrió África y Oceanía y el 11 de marzo se declaró lo impensable: estábamos ante una pandemia (1).

Se tomaron medidas extraordinarias para evitar la propagación de la nueva enfermedad Covid-19: higiene frecuente de manos, uso de antisépticos, distanciamiento social, detención del transporte público, confinamiento, trabajo remoto, toques de queda, cierre de ciudades y de fronteras. El personal de salud fue empujado al límite y obligado a llevar pesados y asfixiantes equipos de protección personal con mascarillas, guantes y ropas desechables. Se logró el objetivo de apagar el fuego en China, Corea y Singapur y se desató el voraz incendio en Estados Unidos, México y Brasil. La ciencia alzó su voz, se desarrollaron vacunas velozmente por grupos de investigadores en actividad frenética, mientras enfermaban más personas y perecían muchos.

El año 2021 inició de manera tímida, sin grandes celebraciones, compartiendo solamente con los más íntimos y con la esperanza de la vacunación masiva. A medida que avanza la lucha contra la enfermedad, las medidas de contingencia, entre ellas la cuarentena, han desplazado el trabajo presencial a remoto en muchos casos y los hogares se han convertido en áreas de trabajo y de recreación, ocasionando que los residuos orgánicos e inorgánicos además de la carga de elementos sanitarios desechables se acumulen por toneladas.

En la carrera por mantener la salud pública, se ha dejado a un lado la preocupación por el impacto de los residuos en la naturaleza. El manejo de los residuos y el reciclaje se han disminuido en los países, debido al temor al contagio del virus mientras que se producen más basuras (2). Aproximadamente 280 millones de toneladas de materiales plásticos se producen en el mundo anualmente y en su mayoría terminan en vertederos o en los océanos. Los científicos han estimado que en los océanos del mundo prevalecen un mínimo de 5,25 billones de partículas de plástico con un peso de casi 269.000 toneladas (3).

Saldremos de nuestros hogares y ciudades y veremos el mundo. Viajaremos para disfrutar las vacaciones aplazadas y encontraremos un planeta más desgastado por una mayor carga de contaminación ambiental que a su vez ocasionará más calentamiento global, incendios forestales, extinción de especies, muerte de los corales por calentamiento y acidificación de las aguas, desplazamiento de la fauna fuera de su hábitat y entonces tendremos el escenario perfecto para empezar nuevamente la pesadilla.

No aprendemos que en el delicado balance entre los seres vivos y el planeta que habitamos reside nuestro sustento y nuestra salvación. Aunque el esfuerzo personal y colectivo por disminuir el estrés del planeta es valioso, son los estados 
quienes deben educar, regular la industria y establecer normas para garantizar la supervivencia de las especies, incluso la humana.

Seguramente la humanidad ganará también esta batalla. Seremos vacunados y aprenderemos a convivir con el patógeno agresor. Sin embargo, surge la paradoja de que mientras la raza humana busca no perecer a causa de la pandemia, se exacerba el problema ambiental, aumentando el riesgo de sucumbir a pesar de todo.

María Cecilia García Espiñeira Médica Patóloga; Ph.D. en Toxicología Ambiental Profesora

Facultad de Medicina Universidad de Cartagena

\section{REFERENCIAS}

1. Organización Mundial de la Salud 2020. Palabras de apertura del Director General de la OMS en la conferencia de prensa sobre COVID-19-11 de marzo de 2020. URL: https://www.who.int/dg/speeches/detail/who-director-general-scomentarios-de-apertura-en-los-medios-informativos-sobre-covid-19 --- 11-marzo$\underline{2020}$

2. Dharmaraj, S., Ashokkumar, V., Hariharan, S., Manibharathi, A., Show, P. L., Chong, C. T., \& Ngamcharussrivichai, C. (2021). The COVID-19 pandemic face mask waste: A blooming threat to the marine environment. Chemosphere, 272, 129601. Advance online publication. https://doi.org/10.1016/j.chemosphere.2021.129601

3. Xuan-Thanh B., Thi-Dieu-Hien V., Phuong-Thao N., Van-Truc N., Thanh-Son D., Phuoc-Dan N. Microplastics pollution in wastewater: characteristics, occurrence and removal technologies. Environ. Technol. Innov. 2020; 19: 101013 